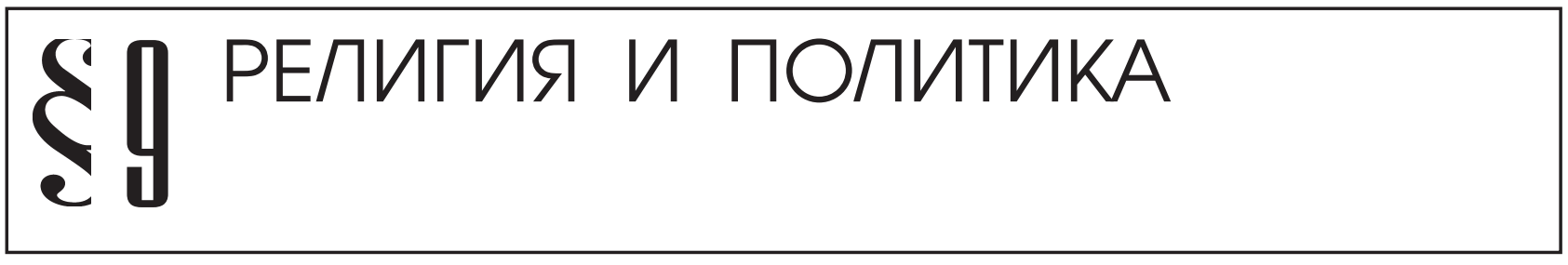

Никитин A.B.

\title{
ПРОТИВОПРАВИТЕЛЬСТВЕННАЯ ДЕЯТЕЛЬНОСТЬ ПРЕДСТАВИТЕЛЕЙ ПРАВОСЛАВНОГО ДУХОВЕНСТВА В ГОДЫ ПЕРВОЙ РУССКОЙ РЕВОЛЮЦИИ: ПО МАТЕРИАЛАМ ЦЕРКОВНОГО СУДОПРОИЗВОДСТВА
}

Аннотация: B статье рассмотрены особенности ичерковного судопроизводства по делам о противоправительственной деятельности представителей православного духовенства Российской империи в годы первой русской революичи (1905 - 1907 гг.). Данная тема недостаточно разработана исторической наукой: при общеизвестности самих фактов репрессивного воздействия священноначалия на оппозииионных клириков, конкретное содержание возникавщих дел крайне редко становится предметом внимания авторов исследовательской и учебной литературы. Однако имеюшаяся источниковая база, хотя и недостаточная для воссоздания полной картины явления, позволяет в значительной степени продвинуться вперед в его изучении. Рассматривая материальл следственных производств, автор сопоставляет подходы различных властных институтов к проблеме пресечения противоправительственной деятельности духовенства, а также приводит примеры поведения самих представителей духовенства в сложившейся кризисной обстановке. Имело место сложное взаимодействие органов государственных и цеерковных (центральных и епархиальных) органов управления. Святейшему Синоду принадлежала решающая роль в ужесточении консисторских приговоров по ряду дел. Неопределенность критериев политической неблагонадежности повсеместно способствовала применению участниками судопроизводства аргументации субъективного характера. Также имели место случаи выдвижения клеветнических обвинений с иелью разрешить в свою пользу бытовые конфликты в приходе.

Review: The article is devoted to peculiarities of church proceedings on antigovernment activity of representatives of the Orthodox Church in the Russian Empire in the years of the first Russian revolution (1905 - 1907). The present topic is understudied by historical sciences. Even though the repressive influence of the hierarchy on oppositional clerics is commonly known, a specific content of particular cases have been rarely a focus of attention of researchers and academicians. However, even though the current base of sources is insufficient to create a full picture, it still allows to progress in studying this phenomenon. Viewing the materials of court proceedings, the author of the present article compares approaches of different governmental institutions to the problem of suppressing anti-government activity of the priesthood and provides examples of behavior of priests in this crisis situation. According to the author, there was also the complex interaction between state authorities and church authorities (both central and eparchial ones). The Holy Synod played a decisive role in strengthening consistorial sentences in a number of cases. Uncertainty of criteria of political unreliability made participants of legal proceedings to use argument of subjective character. There were also cases when calumniatory claims were made with the intention to solve domestic problems for one's benefit in the parish. Ключевые слова: Русская православная иерковь, Святейший Синод, иерковный суд, первая русская революиия, Государственная Дума, консистория, лишение сана, запрещение в священнослужении, религия, судопроизводство.

Keywords: Russian Orthodox church, Holy Synod, church court, the first Russian revolution, State Duma, consistory, defrocking, prohibitions in priesthood, legal proceedings. 
И стория Православной церкви в России, ее взаимодействия с государством и роли в общественной жизни в последние десятилетия становится одной из самых актуальных и востребованных отечественной исторической наукой тем. Однако вследствие сложности и многогранности данной проблематики, далеко не все ее аспекты, даже касающиеся наиболее критических периодов русской истории, уже получили должное освещение. Изучается роль церкви в поддержке самодержавной власти, отмечается также и обратная тенденция, а именно рост среди духовенства критических по отношению к монархии настроений ${ }^{1}$. В то же время, до сих пор не достаточно изучены конкретные управленческие действия, осуществляемые церковными властями в целях пресечения противоправительственной деятельности священников. Исследователи, в основном, ограничиваются лишь указаниями на сами факты предания того или иного духовного лица церковному суду или лишения сана ${ }^{2}$. Задачей статьи является более детальное изучение характерных особенностей судопроизводства по таким делам.

Проступки политического характера, вменяемые священнослужителям в вину, были многообразны: неподобающие высказывания, как в церковных проповедях, так и в частных разговорах; распространение запрещенной литературы; служение панихид по погибшим революционерам и т.д. К сожалению, источники пока не позволяют с точностью ответить на вопросы о точном количестве духовных лиц, наказанных по политическим обвинениям в це-

\footnotetext{
${ }^{1}$ Уже классической стала монография Зырянов П.Н. Православная церковь в борьбе с революцией 1905-1907 гг. М., 1984. Оригинальную концепцию предложил М.А. Бабкин в работе «Священство и Царство (Россия, начало ХХ в. - 1918 г.) Исследования и материаль», изданной в Москве в 2011 2. Появляются новые исследования на региональном материале: Платонов Г.М. Православная церковь и общественно-политическая жизнь провинциальной России. 1900-1914 гг.: На материалах Саратовской губернии: диссертация ... кандидата исторических наук. Саратов, 2003. Рягузов С.С. Общественно-политическая деятельность православного приходского духовенства Европейского Севера в конце XIX - начале XX вв.: диссертация ... кандидата исторических наук. Архангельск, 2009, Шепелева Н.Д. Русская православная церковь в социально-политической истории России в начале XX века : На материалах Тамбовской губернии: диссертация ... кандидата исторических наук. М., 2002.

${ }^{2}$ См. напр.: Зырянов П.Н. Указ. соч. С. 159, 173.
}

лом и по каждому из этих обвинений в частности. Причина этого следующая. Основы карательной политики церковных властей в отношени мятежных клириков определил указ Святейшего Синода от 20 декабря 1905 г., гласивший, что «при получении... сведений о предосудительных действиях кого-либо из духовенства, особливо в тех случаях, когда последствием сего является неповиновение законной власти и нарушение государственного порядка, принимать против виновных лиц решительные меры, немедленно удаляя таковых лиц из мест преступной деятельности с запрещением священнослужения впредь до выяснения дела, о действиях же сих лиц, давших повод к обвинению, назначать неотложные следствия» ${ }^{3}$. Мотивация Синода очевидна: в целях пресечения распространения революционных настроений среди населения важно было в первую очередь изолировать заподозренных в симпатиях к освободительному движению священников от своих прихожан, среди которых они могли пользоваться немалым авторитетом. Запрещение же в священнослужении, с одной стороны, являлось стандартной превентивной мерой, применяемой к подозреваемому священнослужителю на время следственных мероприятий, с другой стороны оно также могло послужить вышеназванной цели - ограничить моральное воздействие опального клирика на паству. Именно из-за этого основной статистический источник, крайне важный для общего исследования функционирования церковного суда синодального периода, - епархиальные отчеты о приговоренных к взысканиям священнослужителях, не является таковым для исследования частного вопроса - фактов противоправительственной деятельности клириков в революционные годы. Перемещение в другой приход часто являлось исключительно административной мерой, налагаемой правящим архиереем, а потому не включалось в данные отчеты о судебных приговорах ${ }^{4}$; то же можно

\footnotetext{
${ }^{3}$ Церковные Ведомости. 1906. №1. С. 6-7.

${ }^{4}$ Одной из наиболее часто подвергавшихся критике характерных черт церковного суда в дореволюционной России являлось соединение суда и администрации. Судебные решения консистории поступали на утверждение правящему архиерею, который имел полномочия как утверждать, так и отменять их. Помимо этого, у архиерея были также чисто административные возможности воздействия на священноцерковнослужителей, например, перемещение в другой приход (но такое же наказание могло быть наложено и после
} 


\section{Политика и общество 8 (116) • 2014}

сказать о временном запрещении в священнослужении на время следствия (мера, не имеющая прямого отношения к итоговому вердикту). Кроме того, в отчетах часто опускалась информация о незначительных взысканиях (например, о выговорах, которые часто выносили подобным правонарушителям $)^{5}$. Для воссоздания более полной картины изучаемого явления можно было бы обратиться именно к отчетам о временном запрещении в священнослужении на время следствия. Однако недостаток этого статистического источника также очевиден: далеко не всегда известно, какой именно запрещенный иерей был в дальнейшем осужден, а какой оправдан. Выяснить хотя бы приблизительное число наказанных по политическим мотивам священнослужителей помогает отчет обер-прокурора по ведомству православного исповедания за 1905-1907 гг., в котором соотношение лояльного и оппозиционного духовенства описывается следующим образом: «Подвиг терпения, любви и молитвы русское духовенство несло, не ослабевая. Явились и из его среды предатели, отверженные ныне церковным судом и осужденные народною совестью, - но они, слава Богу, считались единицами, были колеблющиеся, сбитые с толку, шедшие на сближение с врагом.., - но их, к счастью, были сотни из всей 50-тысячной Христоносной рати русского православного духовенства. Эти тысячи неведомых миру скромных подвижников... явились орудиями великого чуда милости Божией, которою даны умирение и просветление обманутому народу» ${ }^{6}$. Собранные статистические данные позволяют сделать предварительный вывод

рассмотрения дела консисторией). Де-факто епископ реализовывал свою единоличную пастырскую власть в обоих случаях; исследовательская же проблема заключается в том, что статистические сводки судебных дел по епархиям зачастую включали в себя только решения, проходящие через «судный» стол консистории.

5 Так, имеется ведомственная переписка, в которой ярославский архиепископ Иаков (Пятницкий) сообщает о мерах, примененных им к священнику Кремлевскому (выговор), Воздвиженскому и Розову (перемещение в другие приходы). РГИА Ф.797. Оп.76 (ІІотд. 5 стол). Д.10а. ЛЛ. 21-22. Однако ни в отчетах о приговоренных к наказаниям за 1906 г., ни в общем епархиальном отчете за тот же год, данные сведения не приводятся. См.: РГИА Ф.797. Оп.76 (ІІІ отд. 5стол). Д.88., Ф.796. Оп. 442. Д. 2191.

6 Всеподданнейший отчет Обер-прокурора Святейшего синода по ведомству православного исповедания за 1905 1907 гг. С.3. о том, что количественные оценки отчета обладают достаточной степенью точности ${ }^{7}$.

Само «отвержение предателей» церковным судом было весьма неоднозначным процессом, ход которого находился в большой зависимости от конкретных условий той или иной местности империи. Нередко высказывались мнения, что церковные власти не справляются со своими обязанностями. Так, в октябре 1906 г. исполняющий должность пензенского губернатора С.В. Александровский докладывал П.А.Столыпину: «С первых же дней своей службы в Пензенской губернии я убедился, что среди духовенства есть немало лиц, которые играют весьма видную роль в распространении преступной агитации между крестьянами... Не считая, однако, удобным возбуждать против священнослужителей преследований в обычном порядке, я всякий раз сообщал Владыке о преступных действиях того или иного священника, рассчитывая на энергичное и быстрое с его стороны расследование дела и скорое наказание виновных. Но все мои расчеты, к великому сожалению, оказались напрасными. Духовные следствия, которые, к слову сказать, ведутся по несколько месяцев, в результате дают обыкновенно или полное оправдание и, следовательно, безнаказанность виновных, или в редких случаях - замечания» ${ }^{8}$. Бездействие епархиальных властей во многих случаях можно объяснить волокитой, присущей церковному судопроизводству как таковому. Однако некоторые иерархи вполне осознанно выступали против правительственных чиновников. Епископ Смоленский и Дорогобужский Петр (Дугов) в письме обер-прокурору А.А.Ширинскому-Шихматову раскритиковал действия местной администрации, побуждавшей его переводить подозреваемых священников в другие приходы. Ссылаясь на «жестокие нападки на административный произвол» со стороны либеральной печати, как светской, так и церковной, владыка делал вывод: «Посему в наложе-

\footnotetext{
${ }^{7}$ Например, согласно ведомости о запрещенных на время следствия священнослужителях за 1906 г., по политическим мотивам было запрещено около 100 священников и диаконов. Наверняка далеко не все из них впоследствии были признаны виновными, но нужно учитывать что примерно по 1/3 епархий статистических данных вообще нет, а по остальным епархиям данные тоже могут быть неполными. РГИА Ф.797. Оп.76 (ІІІ отд. 5стол). Д.88.

${ }^{8}$ РГИА Ф.796. Оп.187. Д.6856. ЛЛ. 83-85.
} 
нии наказаний в настоящее время более чем когда-либо должна быть наблюдаема осторожность, особенно взысканий тяжких, каковым признается перемещение с одного места на другое без прошения... Гражданское начальство за последнее время к прискорбию присваивает себе совсем не принадлежащее ему право суда над духовными лицами, посягая даже на их личную свободу и не встречая, к еще большему прискорбию, себе должного отпора» ${ }^{9}$. С другой стороны, часть епископата заняла охранительную позицию. Таврический преосвященный Алексей (Молчанов) последовательно применил суровые меры против целой группы ялтинских священников, несмотря на то, что среди их прихожан имелся ряд знатных и влиятельных лиц, неоднократно ходатайствовавших о смягчении наказания ${ }^{10}$. Ярославский губернатор, сообщая сведения о неблагонадежных священниках, специально оговаривал, что не имеет оснований сетовать на недостаток внимания со стороны архиепископа Иакова (Пятницкого) к своим заявлениям или ходатайствам ${ }^{11}$.

В сложившихся условиях Святейший Синод, в основном, использовал свои полномочия для проведения более жесткой политики в тех местностях, где епархиальное начальство терпимо относилось к противоправительственной деятельности клириков. Иногда возникавшие дела приобретали почти гротескный характер. Так, в Пермской епархии при обыске у обывателя Серебрянского завода обнаружены 4 брошюры противоправительственного содержания с оттисками штемпеля священника завода Петрова. В ходе первого следствия консистория удовлетворилась объяснением священника, сводившимся к тому, что «противоправительственными» эти брошюры были только с точки зрения самого правительства, а не с его, священника И.Петрова ${ }^{12}$. Исполняющий должность губернатора А.В.Болотов обратился к товарищу министра внутренних дел А.А. Макарову, а тот в Синод, который и отправил дело в епархию на пересмотр. Члены Синода логично указали, что во время первого следствия «пермское епархиальное начальство ограничилось

\footnotetext{
${ }^{9}$ РГИА Ф.797. Оп. 76. (ІІІ отд. 5стол) Д.8. ЛЛ. 1280б.-129.

${ }^{10}$ РГИА Ф.796. Оп. 187. Д. 6574.

${ }^{11}$ РГИА Ф.797. Оп.76 (ІІІ отд. 5стол). Д.10а. Л.13.

${ }^{12}$ РГИА. Ф.796. Оп. 188. Д. 7059. Л. 11.
}

объяснением названного священника в том, что принадлежащие ему брошюры были не противоправительственного содержания, но не входило в рассмотрение по существу содержания помянутых брошюр, а также приходской деятельности священника Петрова вообще» ${ }^{13}$. Уже во время второго следствия консистория проанализировала брошюры и признала две из них («Программу кадетов» и «Пересмотр аграрной программы рабочей партии») безусловно противоправительственными. Версия о несознательном характере поступков священника была отвергнута, но приговор оказался довольно мягким: месячная епитимия в Белогорском монастыре «за неосторожное обращение с брошюрами противоправительственного содержания, выразившемся в снабжении таковыми некоторых прихожан и признание их непротивоправительственными» ${ }^{14}$. Синод, однако, снова пересмотрел решение епархиального начальства и, указав, что подсудимый не принес покаяния, а также «обнаружил несоответствующее служению в священнической должности направление», заменил епитимию низведением в причетники «впредь до раскаяния и исправления» и переводом в другой приход ${ }^{15}$.

Но особенно активным было участие центральной церковной власти в делах тех священнослужителей, которые своей оппозиционной деятельностью заслужили всероссийскую известность, например, депутатов Государственной Думы. Видное общественное положение делало их важными фигурами в политической борьбе. Ряд священников, входивших в состав Первой Думы, подписали после ее роспуска Выборгское воззвание; несколько священников - депутатов Второй Думы приняли участие в известной акции левых фракций - не явились на заседание 7 мая 1907 г. Впоследствии все они были лишены сана и исключены из духовного звания. Соблюдая установленный порядок, Синод поручал разбор таких дел епархиальным консисториям, как судам первой инстанции, хотя в большинстве случаев это не имело особого значения. Так, судьба пяти священников - участников акции 7 мая определилась практически сразу после этого события, когда им было предписано явиться для личных объясне-

\footnotetext{
${ }^{13}$ Там же. Л. 9.

${ }^{14}$ Там же. Л.13.

15 Там же. Л.14.
} 


\section{Политика и общество 8 (116) • 2014}

ний к митрополиту Санкт-Петербургскому Антонию (Вадковскому). Примечателен текст синодального определения: в нем четко указано, что они должны представить митрополиту объяснения по поводу своего поведения и затем публично объявить о выходе из оппозиционных партий, в противном же случае добровольно сложить с себя сан; а если не пожелают сделать и этого, то их дела следует передать на рассмотрение епархиальному начальству, «из подчинения которым они, как продолжающие быть священниками, не освобождены и в их положении членов Государственной Думы» ${ }^{16}$. Таким образом, в тексте определения фактически содержалась синодальная интерпретация сложившейся ситуации, которую епархиальные суды не могли не принимать во внимание. Неудивительно, что все четыре подвергнутых суду священника - Ф.В. Тихвинский, А.В. Архиппов, А.И. Бриллиантов и К.А. Колокольников (А.И.Гриневич смог оправдаться перед митрополитом Антонием и избежал наказания) были лишены сана. Любопытна реакция осужденных на приговор: Ф.В. Тихвинский подал апелляцию в Синод (которую тот, впрочем, не удовлетворил), А.И. Бриллиантов выразил удовольствие приговором ${ }^{17}$, от А.В. Архиппова и К.А. Колокольникова не было получено ни выражения удовольствия, ни выражения неудовольствия. Таким образом, указанными священнослужителями были продемонстрированы все теоретически возможные варианты поведения в подобной ситуации. Действия же церковных властей были быстрыми и согласованными. Впрочем, иногда и при решении важных политических дел в рядах церковной бюрократии возникало разномыслие. Примером может служить дело депутата Первой Думы, подписанта Выборгского воззвания Н.В.Огнева. Вятская консистория, ссылаясь на то, что «само правительство, как церковное, так и гражданское, вступило на путь разнообразных реформ», а также на отсутствие в проповедях Н.В.Огнева отступлений от догматики и этики православия, приговорила его к отрешению от места. Синод, тем не менее, занял жесткую пози-

${ }^{16}$ РГИА Ф. 796. Оп.187. Д.6881. Л. 31.

17 Замечательна формулировка Бриллиантова: «Хотя подобным судом, в котором не соблюдены самые элементарные формы судопроизводства, нельзя быть удовлетворенным, так как в смысле юридического акта такой суд представляется совершенно фиктивным, однако жаловаться я не намерен и в этом смысле выражаю свое “удовольствие” означенным решением» (РГИА Ф. 796. Оп.187. Д.6881. Л. 105). цию и, отметив, что «указываемые в решении Вятского епархиального начальства в смягчение вины протоиерея Огнева обстоятельства не могут служить основанием к оставлению протоиерея Огнева в священном сане и духовном звании», приказал «отменив решение Вятского епархиального начальства... предписать названному епархиальному начальству постановить о протоиерее Огневе новое решение в соответствии с вышеизложенными указаниями Святейшего Синода» ${ }^{18}$.

Очевидно, что по самому своему характеру обвинения в политической неблагонадежности оставляли большой простор для субъективных интерпретаций. Важное значение имело то, какое именно значение вкладывал священнослужитель в ту или иную произнесенную фразу, как общество воспринимало то или иное богослужебное действие, и т.п. Так, священник Новочеркасской епархии Константин Кузьмин назвал убийц великого князя Сергея Александровича «молодцами», но потом утверждал, что произнес эти слова «не в смысле похвалы и одобрения, а в смысле порицания преступной деятельности убийц великого князя» ${ }^{19} .13$ февраля 1905 г. в Красноуфимском соборе (Екатеринбургская епархия) священник Лев Ершов по просьбе учащихся промышленных классов местного технического училища совершил панихиду по жертвам событий 9 - 10 января в Петербурге. Благочинный в рапорте епископу характеризовал ситуацию следующим образом: «Настроение общественного мнения по поводу служения помянутой панихиды получилось двойственное: одни и преобладающее большинство, во главе с уездным исправником, директором училища, председателем уездного съезда и др., видят в ней характер некоей демонстративности, глумление над долгом гражданским, обнаружение потворства учащейся молодежи и проявление протеста правительственной власти за жертвы беспорядков, другие же, напротив, смотрят на молитву за убиенных, как на долг христианской любви к ближним безотносительно тому, при каких условиях и обстоятельствах стали эти убиенные жертвой беспорядков... не будь отслужена панихида, молодежь могла и в городе затеять беспорядки, и тогда вся нравственная ответ-

\footnotetext{
${ }_{18}^{18}$ РГИА Ф.796. Оп. 187. Ч.2. Д 6809. ЛЛ.50-51.

${ }^{19}$ РГИА Ф.797. Оп.75 (ІІІ отд. 5стол). Д.28. Л.32.
} 
ственность всею своею тяжестью обрушилась бы опять-таки на духовенство» ${ }^{20}$. В Двинске местный священник по требованию собравшихся на соборной площади горожан вынужден был прекратить благовест, как мешающий проведению митинга. Епархиальное начальство расценило его действия как проявление благоразумия ${ }^{21}$, но сам факт возникновения судебного дела свидетельствует и о наличии диаметрально противоположной интерпретации. Другим важным критерием, характеризовавшим мотивацию подозреваемых священников, часто оказывался их интеллектуальный уровень, объективного критерия для измерения которого также не имелось. Одному из священников Новгородской епархии, подозревавшемуся в возбуждении волнений среди местных удельных крестьян, благочинный дал следующую характеристику: «Священник Любомудров известен мне, как человек неглубокого ума, любящий поговорить, сочувствующий современному освободительному движению и желающий добра своим прихожанам» ${ }^{22}$. Совершенно противоположной была оценка управляющего удельным имением: «О деятельности священника Любомудрова имею сведения очень небольшие, он, как человек очень умный, мне... всего не выскажет» ${ }^{23}$.

Говоря о политических делах духовенства, невозможно не упомянуть проблему ложных доносов. Клевета тяжущихся друг на друга была весьма распространенным явлением, с которым церковный суд сталкивался в своей работе постоянно. В революционные годы конфликтующие стороны открыли для себя новый инструмент воздействия - обвинение в политической неблагонадежности, ранее встречавшееся в духовно-судебной практике крайне редко. Так, исполнявший должность псаломщика при Преображенской церкви села Марьинское Михаил Тюмич написал жалобу на священника Троицкой церкви того же селения Л.Лоссиевского, по вине которого якобы не служатся молебствия о прекращении смуты в России, не поется после литургии мно- голетие государю и т.д²4. Однако следствие выяснило, что истинными причинами выдвижения данного обвинения явилась старая вражда священников Л.Лоссиевского (Троицкая церковь) и О.Козака (Преображенская церковь). Интерес же самого псаломщика Тюмича состоял в том, чтобы поселиться в церковном доме при Преображенской церкви (в нем, за неимением удобного помещения у новой Троицкой церкви, проживал Л.Лоссиевский); было установлено, что он угощал свидетелей водкой, убеждая дать нужные ему показания ${ }^{25}$, а также совместно с В.Козаком, сыном священника О.Козака, посещал Троицкую церковь «с целью найти повод к доносу на Лоссиевского» ${ }^{26}$. Кроме того, оказалось, что богослужебные упущения были характерны и для священника О.Козака в его Преображенской церкви. Вина недавно назначенного в новую Троицкую церковь священника Л.Лоссиевского состояла, по заключению консистории, «лишь в том, что [он] по вступлении в должность настоятеля Троицкой церкви не позаботился вывести этой обычной уже в с.Марьинском небрежности, перенесенной псаломщиками и певчими в Троицкую церковь из Преображенской церкви» ${ }^{27}$. М.Тюмич за ложный извет был уволен из епархиального ведомства, а О.Козаку сделано внушение ${ }^{28}$.

Итак, в годы первой русской революции церковные власти использовали ряд мер административного и судебного характера с целью противодействия оппозиционной политической активности определенной части клира. Несмотря на наличие нормативных правовых актов, задающих основы деятельности церковных властей в данном направлении, реальная духовно-судебная практика отличалась многообразием и неоднородностью. Многое зависело от воззрений и личных качеств епархиального архиерея, а также от особенностей конкретных дел. В целом же факт противоправительственных выступлений священнослужителей свидетельствовал о кризисных явлениях в жизни русского православия начала XX века.

\footnotetext{
${ }^{20}$ Там же. Л.53.

${ }^{21}$ Там же. Л.106.

22 РГИА Ф.797. Оп.76 (ІІотд. 5 стол). Д.10а. Л. 664.

${ }^{23}$ Там же. Л. 666.
}

\footnotetext{
${ }^{24}$ Там же. Л. 419.

${ }^{25}$ Там же. Л.421об.

26 Там же. Л.423.

27 Там же. Л.422об.

${ }^{28}$ Там же. Л.423.
} 


\section{Политика и общество 8 (116) • 2014}

\section{Библиография:}

1. Всеподданнейший отчет Обер-прокурора Святейшего синода по ведомству православного исповедания за 19051907 гг. СПб, 1910 г.

2. РГИА Ф.796. Оп.187. Ч.2. Д. 6574.

3. РГИА Ф.796. Оп.187. Ч.2. Д.6856.

4. РГИА Ф.796. Оп.187. Д.Ч.2. 6881.

5. РГИА Ф.796. Оп.187. Ч.2. Д. 6809.

6. РГИА Ф.796. Оп.188. Д. 7059.

7. РГИА Ф.796. Оп.442. Д. 2191.

8. РГИА Ф.797. Оп.75 (ІІІ отд. 5стол). Д.28.

9. РГИА Ф.797. Оп.76 (ІІІ отд. 5стол). Д.8.

10. РГИА Ф.797. Оп.76 (ІІІ отд. 5стол). Д.10а.

11. РГИА Ф.797. Оп.76 (ІІІ отд. 5стол). Д.88.

12. Церковные Ведомости. 1906. №1.

13. Бабкин М.А. Священство и Царство (Россия, начало ХХ в. - 1918 г.) Исследования и материалы. М., 2011.

14. Зырянов П.Н. Православная церковь в борьбе с революцией 1905-1907 гг. М., 1984.

15. Платонов Г.М. Православная церковь и общественно-политическая жизнь провинциальной России. 1900-1914 гг. : На материалах Саратовской губернии : диссертация ... кандидата исторических наук. Саратов, 2003.

16. Рягузов С.С. Общественно-политическая деятельность православного приходского духовенства Европейского Севера в конце XIX-начале XX вв. диссертация ... кандидата исторических наук. Архангельск, 2009.

17. Шепелева Н.Д. Русская православная церковь в социально-политической истории России в начале XX века : На материалах Тамбовской губернии. диссертация ... кандидата исторических наук. М., 2002

\section{References (transliteration):}

1. Babkin M.A. Svyashchenstvo i Tsarstvo (Rossiya, nachalo KhKh v. - 1918 g.) Issledovaniya i materialy. M., 2011.

2. Zyryanov P.N. Pravoslavnaya tserkov' v bor'be s revolyutsiei 1905-1907 gg. M., 1984.

3. Platonov G.M. Pravoslavnaya tserkov' i obshchestvenno-politicheskaya zhizn' provintsial'noi Rossii. 1900-1914 gg. : Na materialakh Saratovskoi gubernii : dissertatsiya ... kandidata istoricheskikh nauk. Saratov, 2003.

4. Ryaguzov S.S. Obshchestvenno-politicheskaya deyatel'nost' pravoslavnogo prikhodskogo dukhovenstva Evropeiskogo Severa v kontse XIX-nachale XX vv. dissertatsiya ... kandidata istoricheskikh nauk. Arkhangel'sk, 2009.

5. Shepeleva N.D. Russkaya pravoslavnaya tserkov' v sotsial'no-politicheskoi istorii Rossii v nachale XX veka: Na materialakh Tambovskoi gubernii. dissertatsiya ... kandidata istoricheskikh nauk. M., 2002 